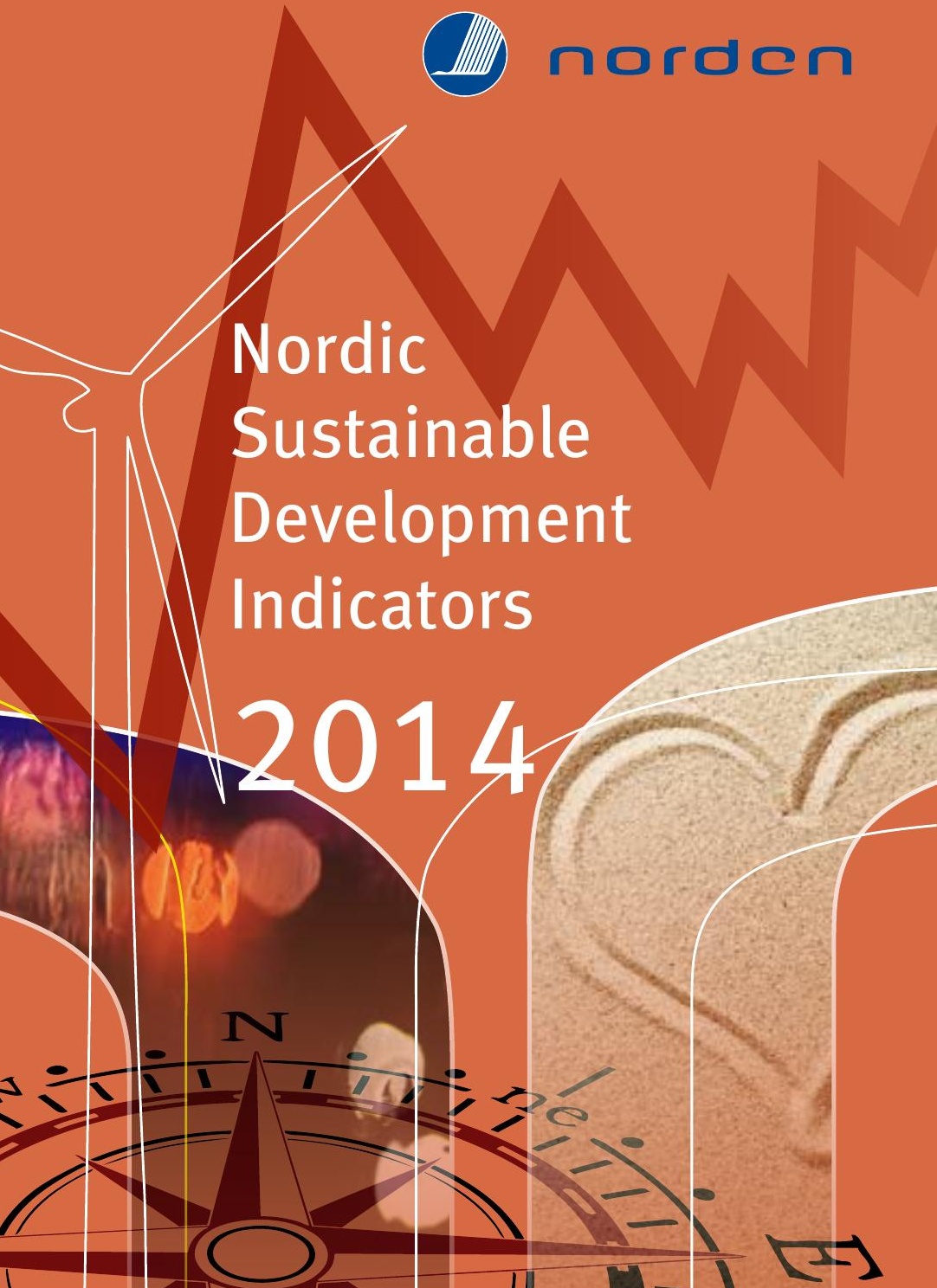




\section{Nordic Sustainable Development Indicators 2014}

ISBN 978-92-893-3810-3 (PRINT)

ISBN 978-92-893-3811-0 (PDF)

http://dx.doi.org/10.6027/ANP2014-755

ANP 2014:755

(C) Nordic Council of Ministers 2014

Cover design: Jette Koefoed/SignElements

Photos: ImageSelect and SignElements

Print: Rosendahls-Schultz Grafisk, Albertslund

Copies: 1500

Printed in Denmark

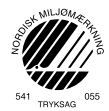

Main suppliers of data: The Nordic national statistical institutes and Eurostat Ed: Klaus Munch Haagensen, Statistics Denmark.

\section{Nordic Council of Ministers}

Ved Stranden 18

DK-1061 Copenhagen K

\section{www.norden.org/en/publications}

\section{Nordic co-operation}

Nordic co-operation is one of the world's most extensive forms of regional collaboration, involving Denmark, Finland, Iceland, Norway, Sweden, and the Faroe Islands, Greenland, and Åland.

Nordic co-operation has firm traditions in politics, the economy, and culture. It plays an important role in European and international collaboration, and aims at creating a strong Nordic community in a strong Europe.

Nordic co-operation seeks to safeguard Nordic and regional interests and principles in the global community. Common Nordic values help the region solidify its position as one of the world's most innovative and competitive. 


\section{Nordic \\ Sustainable \\ Development \\ Indicators \\ 2014}

ANP 2014:755 


\section{Content}

\section{The Nordic welfare model 4}

1.1 Demographic trends 4

1.2 Gross Domestic Product (GDP) 6

1.3 Public debt 7

1.4 Urbanisation 8

1.5 Employment and unemployment rate 9

1.6 Life expectancy at birth 11

1.7 Gini-coefficient 13

1.8 Risk of poverty amongst families with children 14

1.9 Gender pay gap 15

\section{Viable ecosystems 16}

2.1 Sustainability of fish stocks 16

2.2 Discharge of nitrogen and phosphorus into the Baltic Sea 18

2.3 Change in the common bird index 20

2.4 Developments in annual fellings and increments in forests 21

2.5 Urban population exposure to air pollution by ozone and particulates 22
3. Changing climate $\mathbf{2 4}$

3.1 Share of renewable energy in gross energy supply 24

3.2 Developments in greenhouse gas emissions by sector 25

3.3 Emissions and land use, land use change and forestry 28

\section{Sustainable use of earth's resources 29}

4.1 Decoupling of environmental pressures and economic growth 29

4.2 Nordic Ecolabel and the EU Ecolabel 31

4.3 Proportion of environmental taxes in total tax revenues 32

4.4 Development in municipal waste management by treatment method 33

\section{Education, research and innovation 34}

5.1 Educational attainment 34

5.2 Research and development expenditure as a percentage of GDP 36

The symbol $\square$ and the reference that appears below a diagram identifies the table in the database that has served as its source. A click in the PDF version takes you directly to the table in question. On the web page www.norden.org/sdindicators, you can find the Nordic Statistics database and all the data behind the indicators, in more detail.

\section{Symbols}

Nil Less than half 0

Not applicable

Data not available
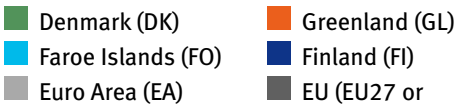


\section{Foreword}

Achieving sustainable development is an ambitious but necessary goal. There is no alternative: we have to improve welfare and quality of life globally and safeguard the earth's ability to support life in all its diversity.

The Nordic countries have established joint objectives for sustainable development in the Nordic region. In addition, the countries have agreed on a set of sustainability indicators that give an overall picture of our progress.

This brochure briefly describes these Nordic Sustainable Development Indicators, which show long-term trends in the following focus areas: the Nordic welfare model; viable ecosystems; changing climate; sustainable use of the earth's resources; and education, research and innovation.

A complete set of key indicators, including separate national graphics, can be found on our website. The website also offers free access to the Nordic Statistics database, which allows you to download data and create graphics for your own analysis.

I believe that our indicators are useful not just for decision makers and civil servants but for all who need reliable information and comparable data on development in the Nordic region.

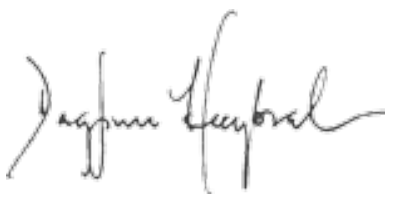

Secretary General

Nordic Council of Ministers 


\section{The Nordic welfare model}

\subsection{Demographic trends}

The indicator shows the population development and the contributing factors: births, deaths and net migration. The population development is shown as an index based on 1990, i.e. you can directly read how much the population has grown compared to the other countries. The contributing factors are here shown as the crude rate, i.e. the number of births, deaths and net migration per 1000 inhabitants.

\section{Population Development. Index 1990=100}
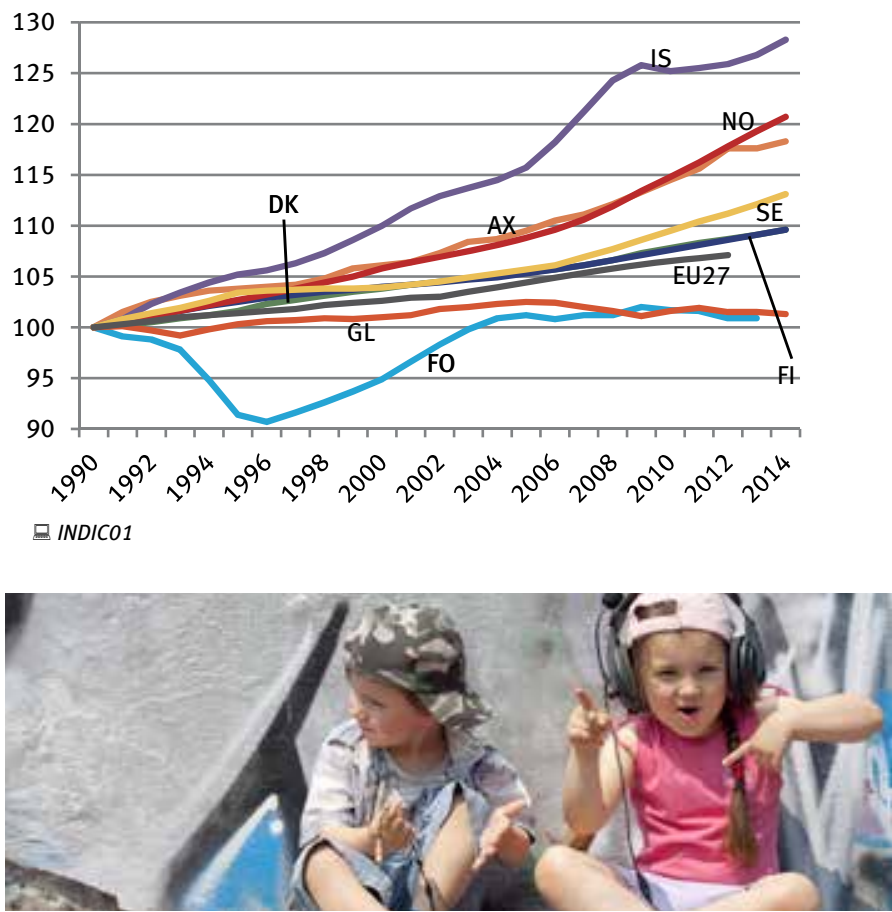
Per 1000 people. 2013

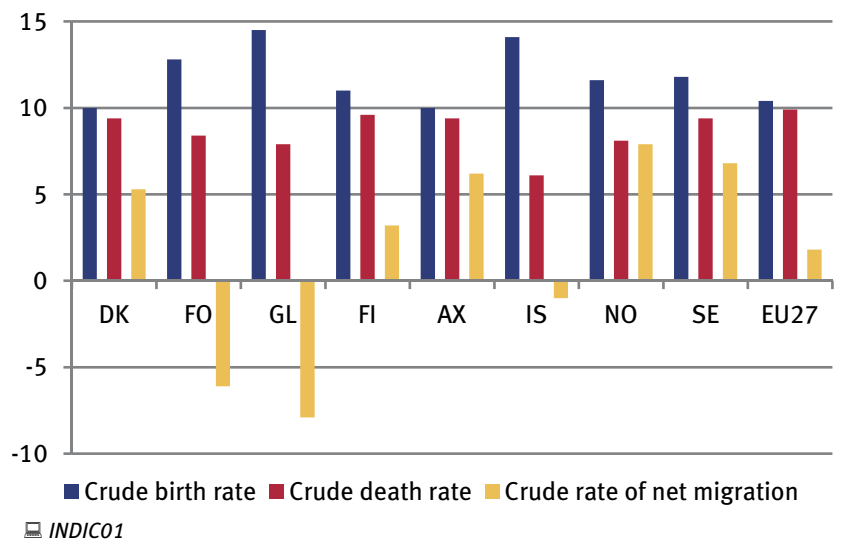

Iceland has had the highest population growth. Its population has increased by 28 per cent since 1990 . The Faroe Islands and Greenland have had the smallest increase, by only 0.9 and 1.3 per cent respectively. With the exception of the Faroe Islands, Greenland and Iceland, net migration contributes most to the increasing population.

Compared to EU27, birth rates in the Nordic countries are generally higher and death rates generally lower. 


\subsection{Gross Domestic Product (GDP)}

The indicator Gross Domestic Product per person shows trends in the nation's general economic situation. Purchasing Power Standards (PPS) have been recalculated, thereby eliminating differences in price levels between countries.

\section{Gross Domestic Product in PPS. Euro per person}

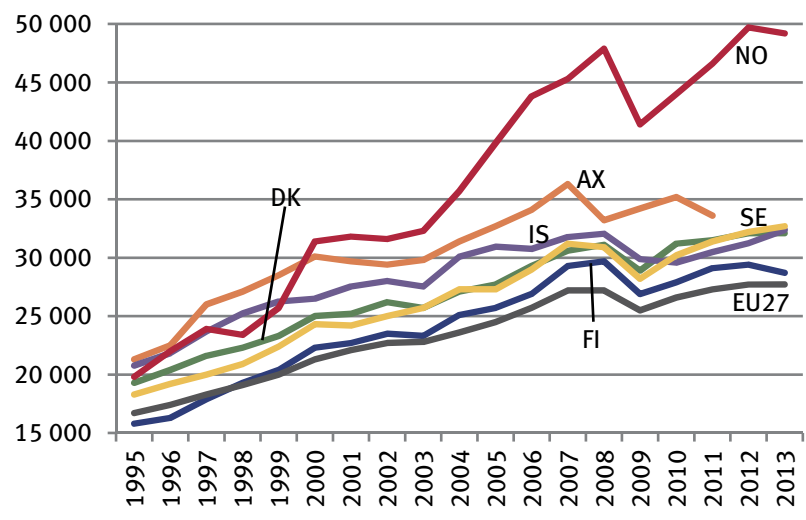

ㅁNINICO2

All of the Nordic countries have a higher GDP per person than the EU. In Norway, the GDP per person is almost twice that of the EU27. Norway is at the top, Sweden and Denmark numbers two and three.

GDP per person has increased in all countries since 1995 but, due to the global financial crisis, GDP declined in all countries in 2009. 


\subsection{Public debt}

The indicator shows the consolidated general government gross debt as a percentage of GDP, as defined in the Maastricht Treaty.

\section{Consolidated general government gross debt. Per cent of GDP}

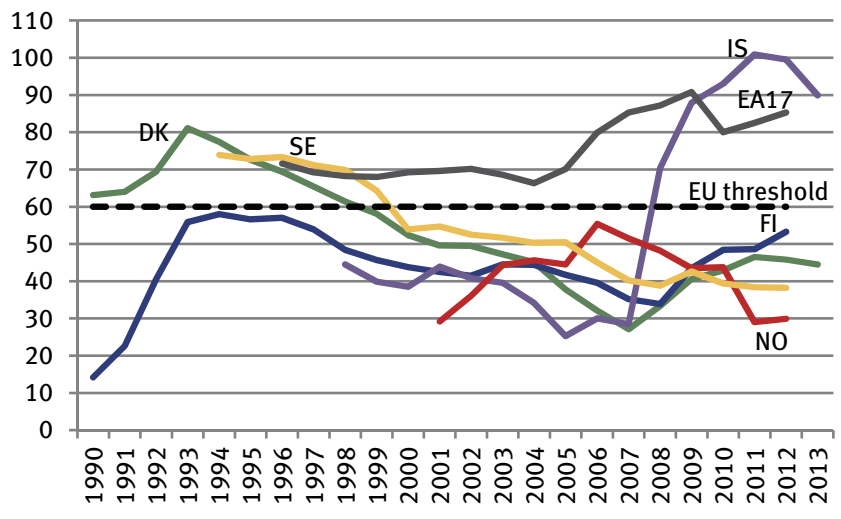

INDICO3

Except for Iceland, the share of debt is lower in all the Nordic countries than in the EU, and all are below the EU threshold of 60 per cent of GDP. However, both Denmark and Finland (and the EU) have experienced a rise in their debt share since the beginning of the financial crisis. 


\subsection{Urbanisation}

The indicator shows the share of the population living in densely, intermediate and thinly populated areas. The populations are placed in the different areas of urbanisation based on the EU definition of Rural grid cells, Urban clusters and High-density clusters.

\section{Degree of urbanisation. Per cent of total population}

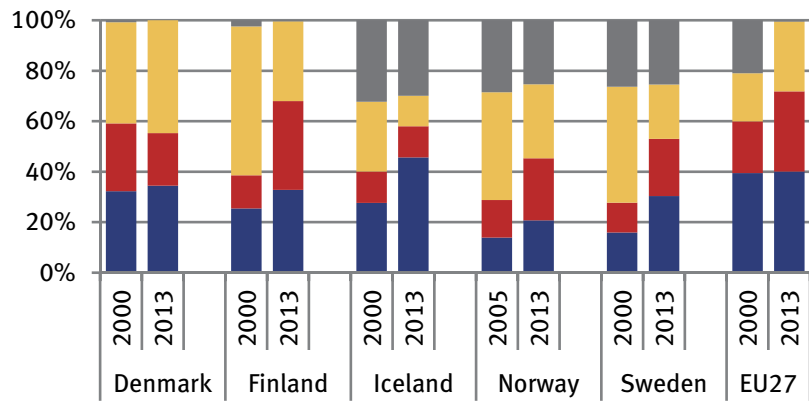

Densely populated area $\quad$ Intermediate urbanised area

Thinly populated area $\quad$ Unknown

몬ㄷㄴ 104

Since 2000, densely populated areas have increased in all the Nordic countries (in Norway since 2005).

In Iceland and in the EU, the largest proportion of the population lives in densely populated areas. Please note that almost 25 per cent of the population in Sweden has been placed in the category "unknown". 


\subsection{Employment and unemployment rate}

The employment rate is defined as the proportion of persons aged 15 to 64 in employment. The EU 2020 target is an employment rate of 75 per cent for the group of 20 to 64 -year-olds.

\section{Employment rate. 15-64 years of age}

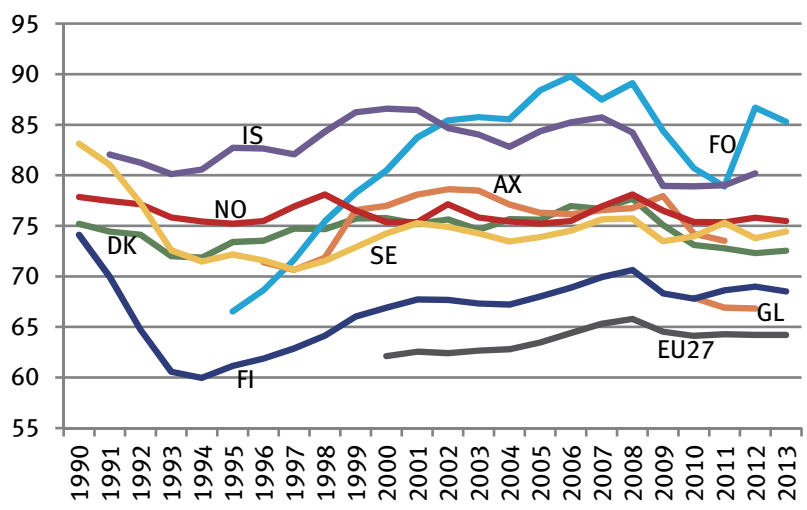

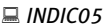

All the Nordic countries with the exception of Finland are close to - or even exceed - the target of an employment rate of 75 per cent for people aged 20 to 64, even when the 15-20-year-olds are included. The employment rate is usually much lower for this latter group. 
The unemployment rate is defined as the number of unemployed persons as a percentage of the labour force. The labour force consists of all employed and unemployed persons in the age group 15 to 64 .

\section{Unemployment rate. 15-64 years of age}

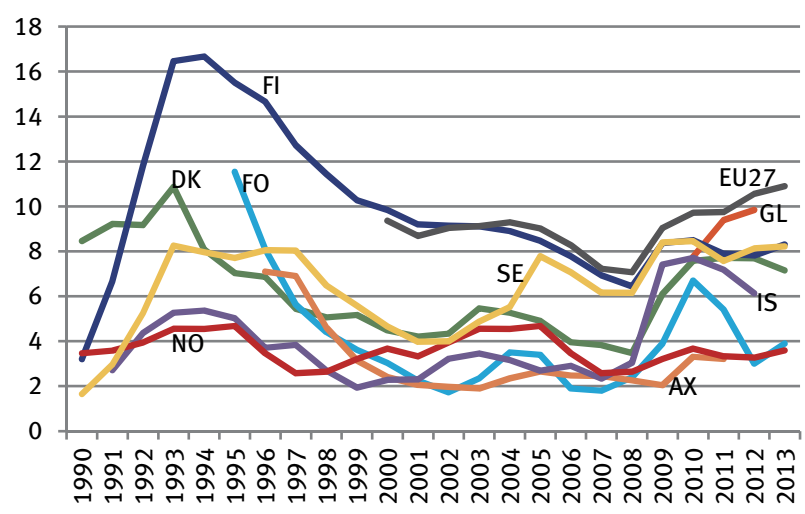

ㅁNDICO5

The overall unemployment rate has fluctuated since the early $1990 \mathrm{~s}$. The current rate has varied from 1.8 per cent in the Faroe Islands in 2007 to almost 17 per cent in Finland in 1994, and was at a maximum in most countries in the early 1990 s and late 2000 s.

All Nordic countries have experienced a rise in their unemployment since the financial crisis began in 2008. In 2013, Denmark, Finland and Sweden had the highest rates between 7 and 8 per cent.

The unemployment rate is much higher for young people aged 15 to 24 than for the population between 15 and 64. In the EU, Finland and Sweden, more than 20 per cent of the people in that group are unemployed. This is more than twice the overall rate. 


\subsection{Life expectancy at birth}

The indicator life expectancy at birth indicates how many years a newborn is expected to live, based on the current patterns of mortality. As the mortality rate differs between men and women (women tend to live longer), life expectancy is calculated separately for men and women.

\section{Life expectancy, years. Men}

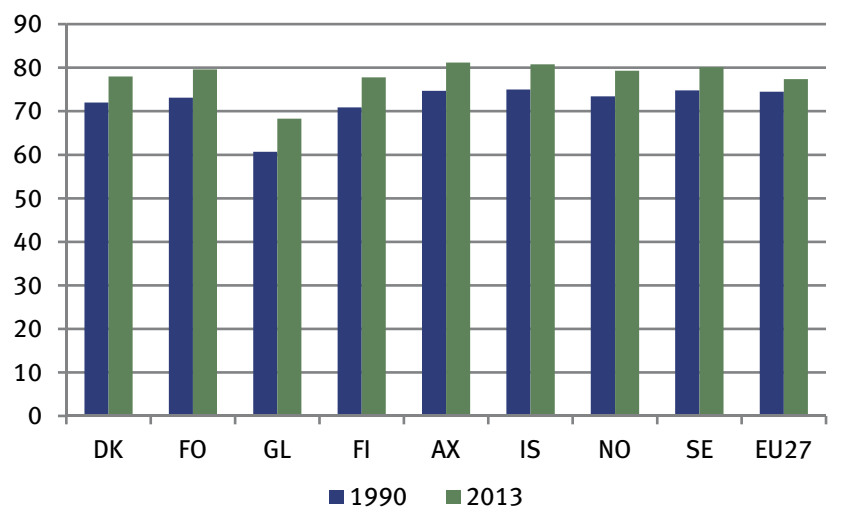

马INDICO6

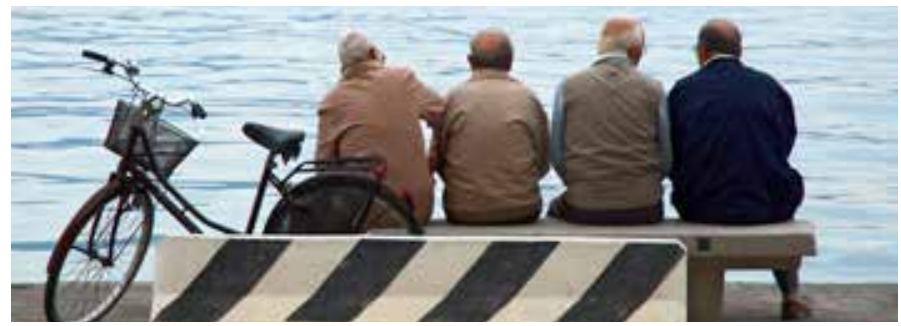




\section{Life expectancy, years. Women}

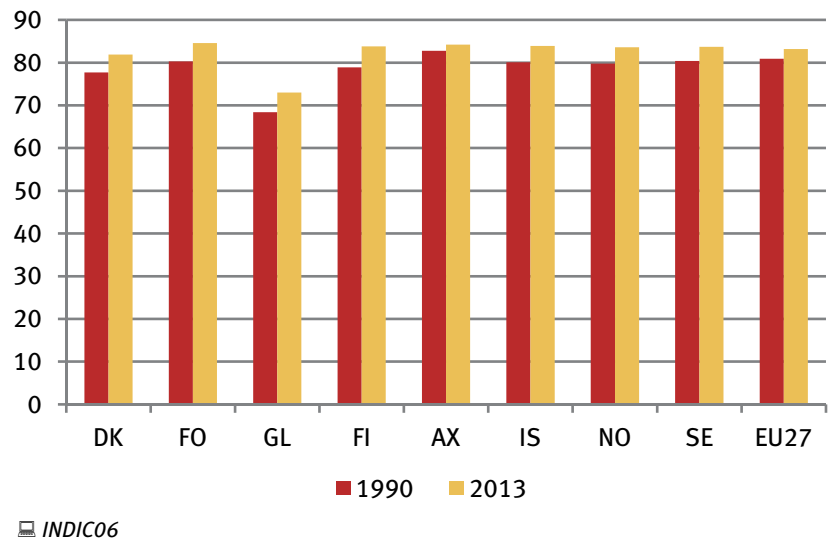

Even though women still tend to live longer, life expectancy for men is increasing, so the gap is closing between the sexes.

Except for the Danish women and the Greenlandic men and women, people in the Nordic countries can expect to live longer than the average European.

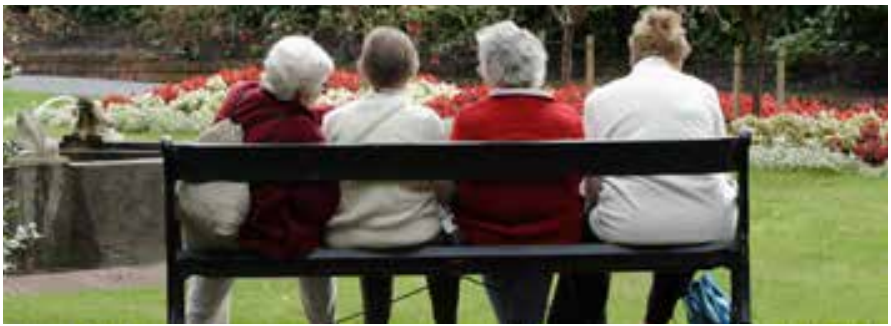




\subsection{Gini-coefficient}

The Gini-coefficient is the most commonly used measure of inequality. The coefficient varies between 0 , which reflects complete equality (when everybody has identical incomes) and 1 , which indicates complete inequality (i.e. one person has all the income or consumption, all others have none).

\section{Gini-coefficient}

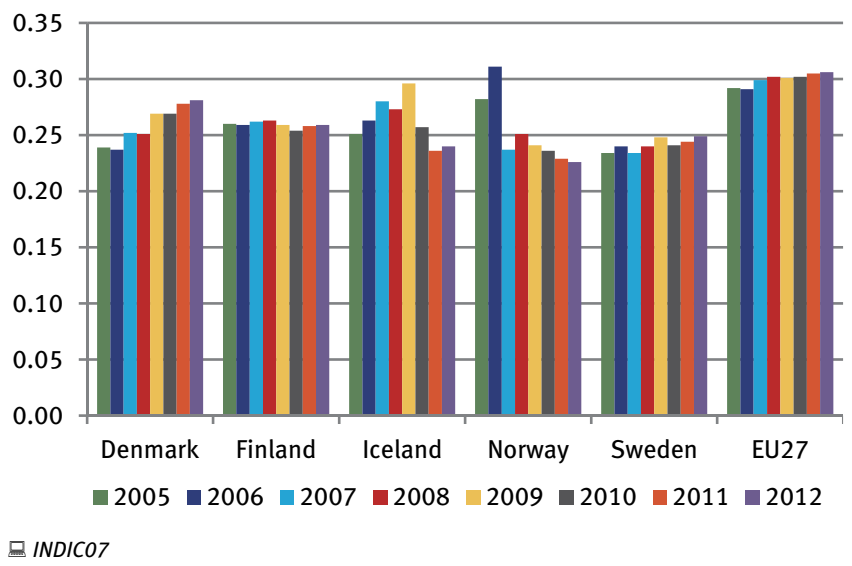

All the Nordic countries are considered to be very equal societies. In recent years (20005 to 2012), inequality has risen in Denmark and Sweden. This trend is also seen in the rest of Europe and among other OECD countries. 


\subsection{Risk of poverty amongst families with children}

The indicator measures the proportion of persons at risk of monetary poverty. Monetary poverty is a key dimension of social inclusion. Persons are at risk of poverty if their equivalised disposable income is below the risk-of-poverty threshold, which in the EU is set at 60 per cent of the national median income after social transfers.

\section{Risk of poverty}

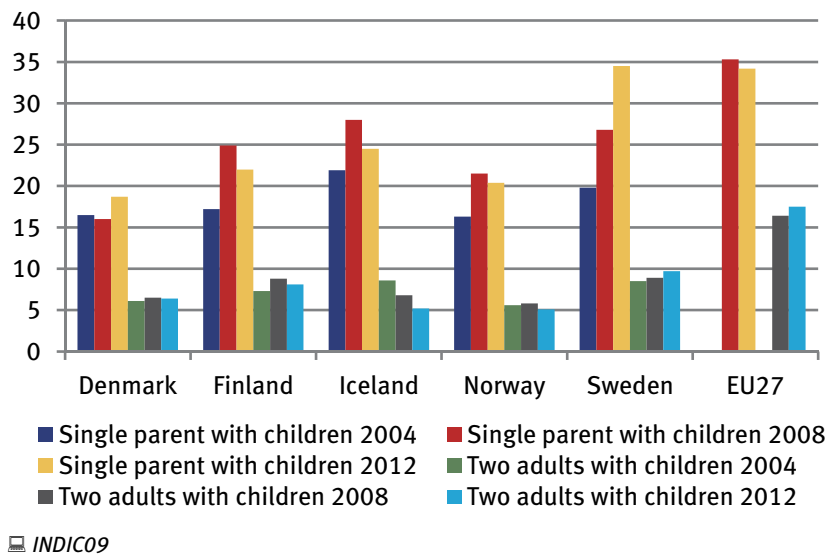

In all the Nordic countries, single parents are at a greater risk of poverty than two adults with children.

In 2012, single parents in Sweden were at the greatest risk of poverty compared with the other Nordic countries and the $27 \mathrm{EU}$ countries.

Since 2004, most countries have experienced an increase in the risk of poverty for both types of households. 


\subsection{Gender pay gap}

The unadjusted gender pay gap represents the difference between average gross hourly earnings of male paid employees and of female paid employees as a percentage of average gross hourly earnings of male paid employees.

\section{Gender pay gap}

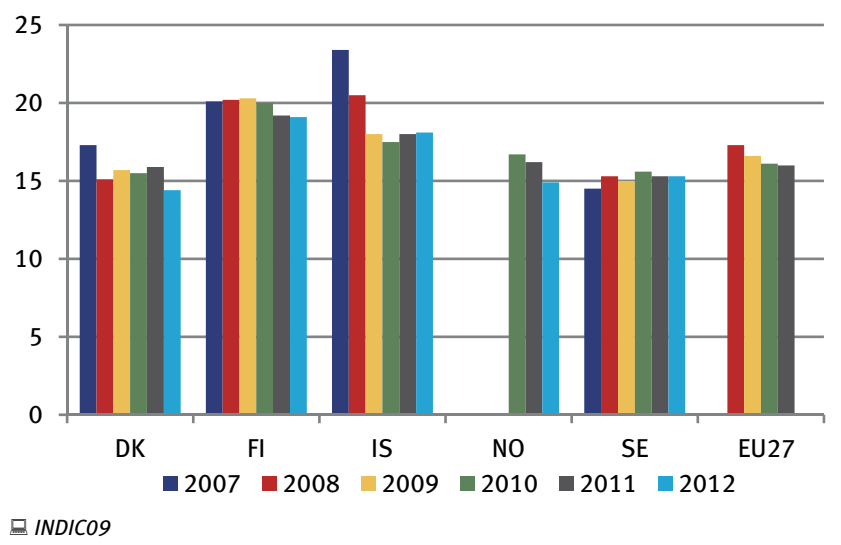

The gender pay gap in Denmark, Norway and Sweden is around 14 to 15 per cent and is generally at the same level as that of the EU. The gap is slightly wider in Finland and Iceland - around 18 to 19 per cent in 2012.

From 2011 to 2012, the gap has diminished in the Nordic countries, besides in Sweden where it has remained the same. 


\section{Viable ecosystems}

\subsection{Sustainability of fish stocks}

The indicator shows trends in the sustainable yield of stocks of fish in 5 marine regions particularly relevant to the Nordic countries. The marine regions are: the Barents and Norwegian Sea, Iceland and East Greenland, the Faroese Plateau, the North Sea and the Baltic Sea.

Ideally, if stock management is good, the Fish mortality sustainable yield ( $F /$ Fmsy) should be around or below 1 . The threshold for sustainable spawning stock mass - the Biomass trigger (B/Btrigger) - has been set at 1 and should therefore be around or above 1 .

Demersal fish, such as cod, hake and haddock, live and feed on or near the sea bed but not in the deepest waters. Pelagic fish, such as herring and mackerel, live and feed away from the sea bed. Benthic fish, such as flounder, sole, turbot, plaice and halibut, live and feed near the sea bed, irrespective of the depth of the water.

\section{Fish mortality sustainable yield F/Fmsy}

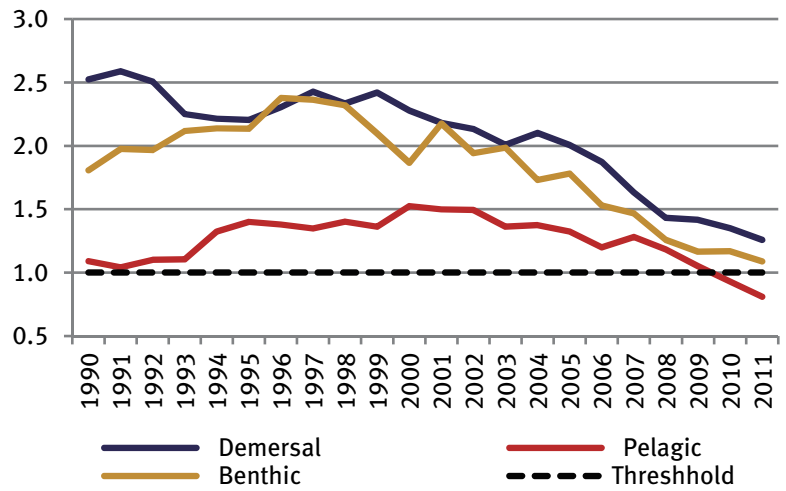

ㅁNDIC201 


\section{Biomass trigger/Btrigger}

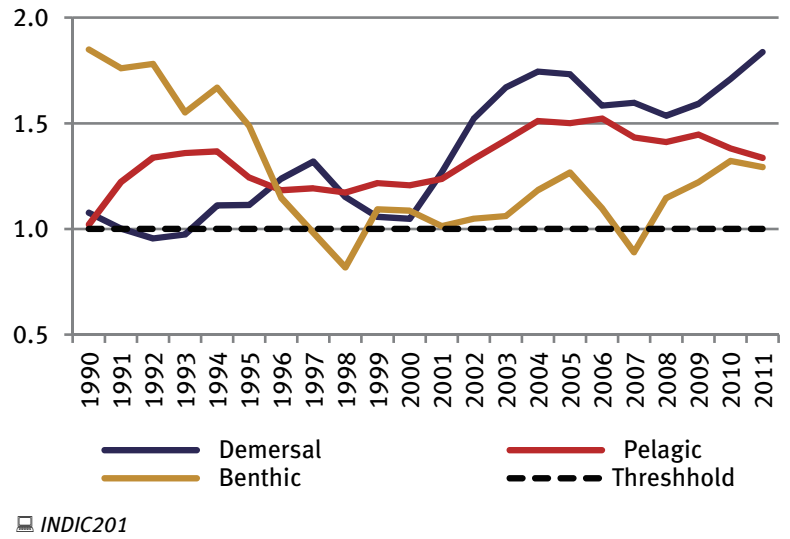

The overall picture regarding trends in fish mortality from 1990 onwards is positive for all types of fish stocks. The indicator for pelagic stocks is below 1 , and below 1.5 for demersal and benthic stocks. The trend is downwards, and therefore positive.

The Biomass trigger has been on the positive side of the threshold since 1990 with some fluctuations below the threshold over the period. In 2011, pelagic and benthic stocks were approximately 1.3 and demersal stocks approximately 1.8 . 


\subsection{Discharge of nitrogen and phosphorus into the Baltic Sea}

The indicator shows the annual discharges of nitrogen and phosphorus into the Baltic Sea from all the countries bordering the Baltic Sea.

Data covers both monitored and unmonitored loads (i.e. loads from unmonitored areas). From parts of the countries surrounding the Baltic Sea (especially Russia), some loads have not been reported. Data concerning loads from the Kaliningrad region (Russia), are missing completely. The load from the Tornionjoki/Torneälv river forming the boundary between Sweden and Finland has been allocated exclusively to Sweden, and the load of the river Narva between Estonia and Russia has been allocated exclusively to Estonia.

\section{Discharge of nitrogen into the Baltic Sea. 1000 tonnes}

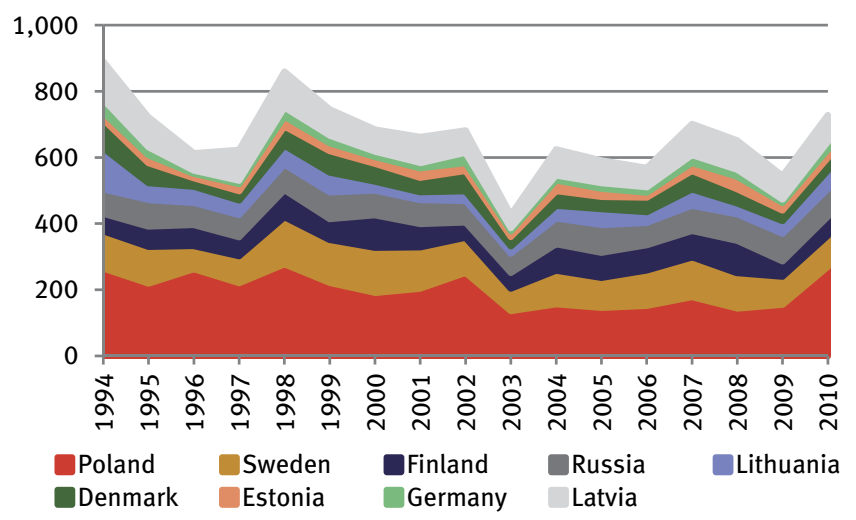

묭 INDIC202 


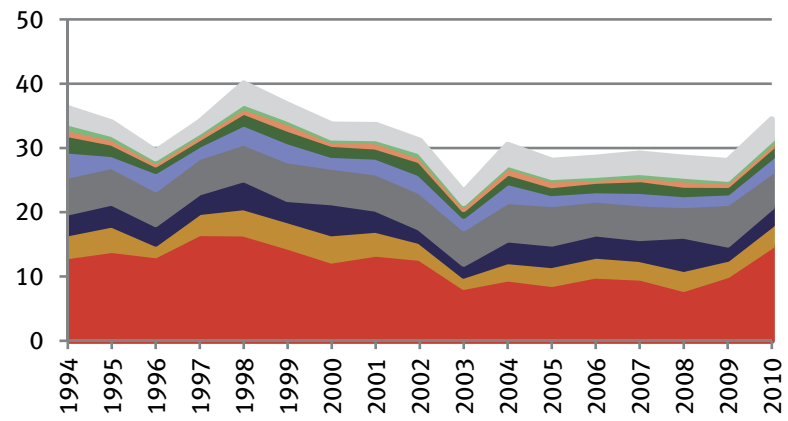

$\begin{array}{llll}\text { apoland } & \text { Sweden EFinland } & \text { Russia Lithuania } \\ \text { DDenmark Estonia } & \end{array}$

ㅁNIC202

The amount of precipitation, and thus the amount of riverine flow, are closely related to the riverine input of nutrients to the Baltic Sea. This can be seen clearly, for example, in the diagrams for 2003. Runoff was very low, so the discharges of both nitrogen and phosphorus were also low.

The largest nitrogen and phosphorus discharges are from Poland. Discharge of nitrogen from Poland is nearly $2 \frac{1 / 2}{2}$ times that of the second country, Sweden, and discharge of phosphorus from Poland is three times that of the second country, Sweden. Russia and Finland are in third and fourth place for both types of discharge. The same four countries also have the largest riverine water runoff in the region.

Total discharge of nitrogen into the Baltic Sea declined from approximately 890000 tonnes in 1994 to approximately 730000 tonnes in 2010 .

Phosphorus discharge decreased slightly between 1994 and 2010 from 36000 tonnes to approximately 34500 tonnes 


\subsection{Change in the common bird index}

The common bird index is an aggregated index integrating the population abundance and the diversity of a selection of bird species associated with specific habitats, as in this example of common farmland birds.

\section{Change in the bird index for farmland. $2000=100$}

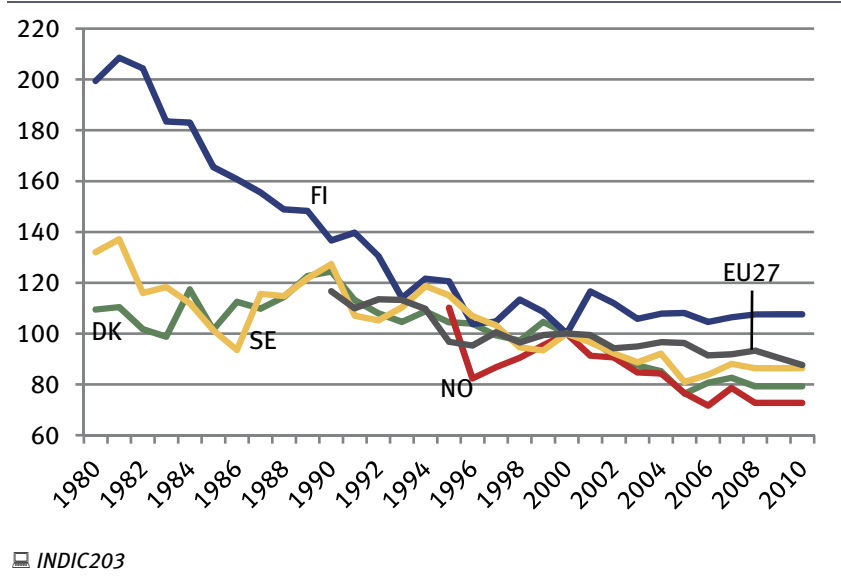

The number of farmland bird species has declined in the Nordic countries and the EU between 1980 and 2010. The largest decline over this period is seen in Finland, where the number of species has almost halved.

In recent years, the decline has slowed for most countries and, in Finland, there has even been a slight increase since 2000 . 


\subsection{Developments in annual fellings and increments in forests}

The indicator shows three trends in forests: the annual amount of forest fellings, the net increment and the annual fellings as a percentage of net annual increment. The latter is shown here.

\section{Forests. Annual fellings as share of net annual increment}

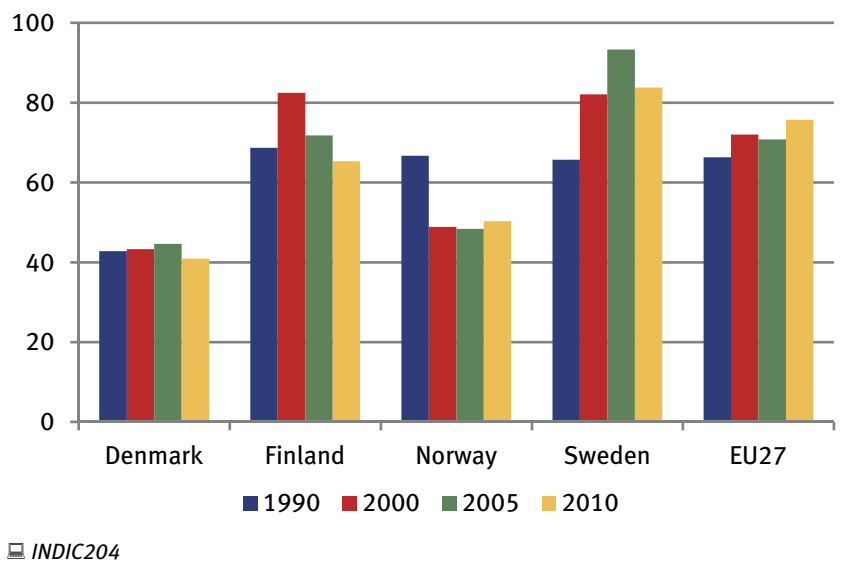

The net annual increment of forests is now greater than in 1990 for all the Nordic countries. Annual fellings are also greater than in 1990, with the exception of Norway.

In all Nordic countries except Norway, there were fewer fellings in relation to the net increment in 2010 than in 2005. In the EU and Norway, the rate of fellings has increased in the same period. 


\subsection{Urban population exposure to air pollution by ozone and particulates}

The first part of the indicator shows the population-weighted annual total of maximum daily eight-hour mean ozone concentrations above a threshold of 70 micrograms of ozone per $\mathrm{m}^{3}$ at background stations in urban areas. The second part of the indicator shows the population-weighted annual mean concentration of particulate matter (PM10) at urban background. Particulate matter (PM10) comprises particles of smaller than 10 micrometers.

\section{Urban population exposure to ozone. Number of hours ${ }^{1}$}

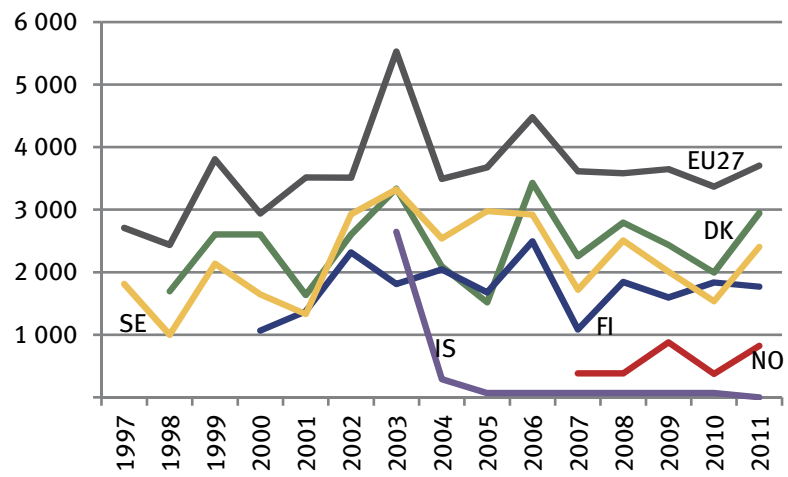

INDIC205 ${ }^{1}$ Number of eight-hours mean concentration (annual sum).

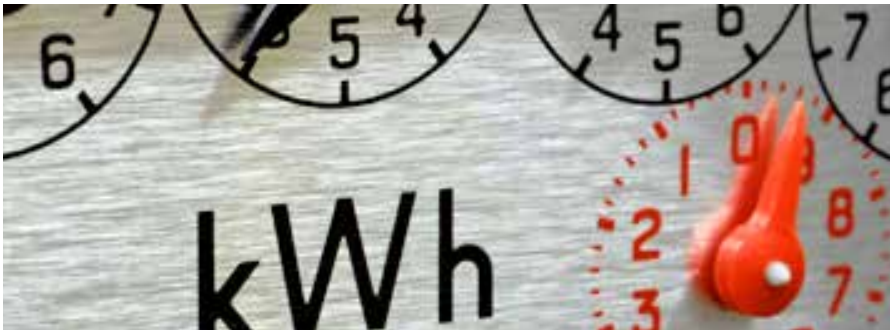




\section{Urban population exposure to particulate matter. $\mathrm{Mg}$ per $\mathrm{m}^{3}$}

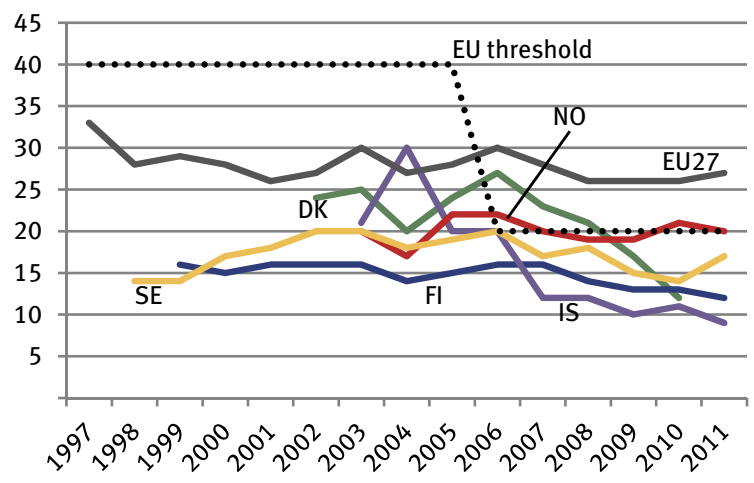

INDIC205.

Urban exposure to ozone widely varies between countries, partly due to differences in climate and vegetation. In general, southern countries with higher summer temperatures show higher exposure levels than the cooler northern countries. Nevertheless, peaks occurred throughout the EU in 2003 and 2006 due to exceptionally high temperatures in those years. This increase was the most pronounced in the northern countries, which showed higher relative increases compared to the southern countries.

In Denmark, Norway and Sweden, there was a decline in the exposure to ozone between 2008 and 2010. But from 2010 to 2011, the levels have gone up in the same three countries.

All Nordic countries and EU countries were well below the EU threshold of 40 micrograms of particulate matter per day per $\mathrm{m}^{3}$ in 2005. In 2006 the threshold was set to 20 micrograms per $\mathrm{m}^{3}$ and all the Nordic countries except for Norway also met this criterion by 2010, with levels below 15 micrograms per $\mathrm{m}^{3}$. However, in 2011, Norway was hitting the target of 20 micrograms per $\mathrm{m}^{3}$. From 2010 to 2011, Sweden has experienced an increase in the levels of particulate matter. 


\section{Changing climate}

\subsection{Share of renewable energy in gross energy supply}

The indicator shows the share of renewable energy in the total energy supply for consumption. Renewable energy sources are hydro-electric, wind, geothermal, wave and solar energy.

\section{Share of renewable energy in gross energy supply. Per cent}

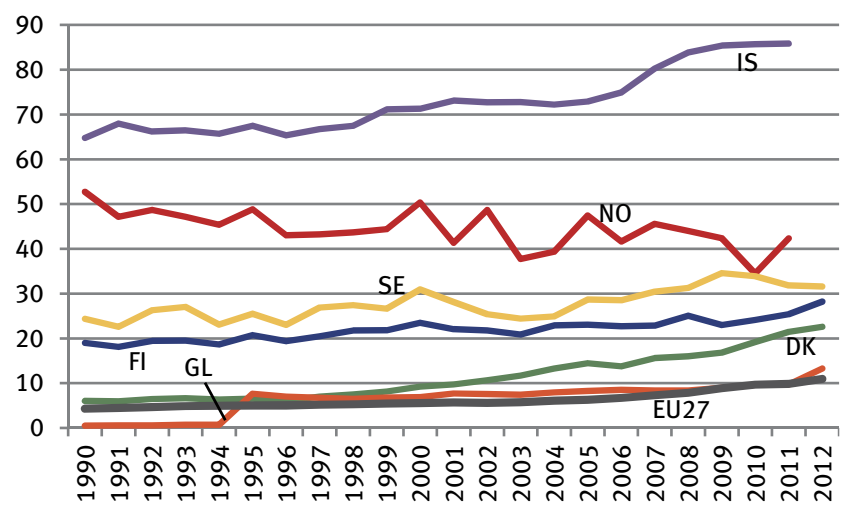

马INDIC301

Due to the availability of natural resources, hydro energy is a major source of renewable energy in some of the Nordic countries, e.g. Norway and Sweden. In Iceland, geothermal power plays the largest role.

Since 1990 , there has been a rise in the proportion of renewable energy in the overall energy supply in the Nordic region - by between 7 and 21 per cent. Iceland and Norway have the highest proportions of renewable energy supply at 86 and 42 per cent respectively.

The biggest change has occurred in Denmark, where the proportion has increased to almost 23 per cent - nearly fourfold in 2012 compared with 1990. 


\subsection{Developments in greenhouse gas emissions by sector}

This indicator shows the contribution of key source categories to total greenhouse gas emissions, and how they change over time. A key source category is defined as an emission source category that has a significant influence on a country's greenhouse gas inventory in terms of the absolute level of emissions, the trend in emissions, or both.

The different greenhouse gases are weighted by their global warming potential, and the results are expressed in $\mathrm{CO}_{2}$-equivalents.

Total greenhouse gas emissions. $1990=100$

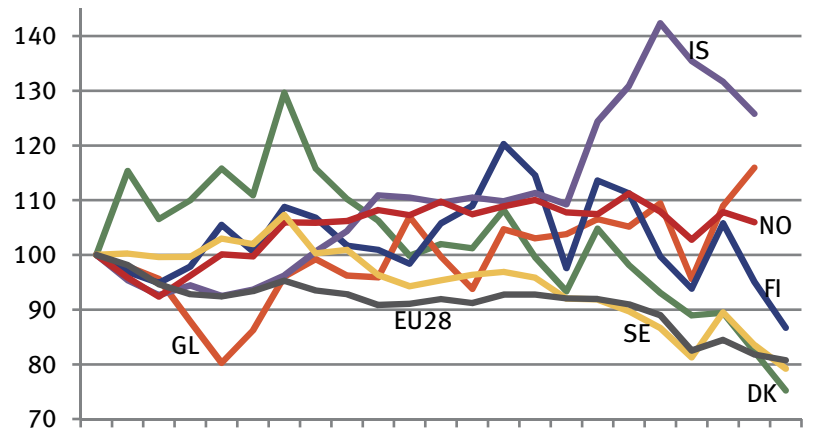

199019921994199619982000200220042006200820102012

모인 302

In Denmark and Sweden, greenhouse gas emissions decreased by between 20 and 25 per cent between 1990 and 2012, but emissions have increased in Norway and Iceland. Iceland has had the highest increase in greenhouse gas emissions, an incease of 26 per cent. 
Greenhouse gas emissions by sectors. Nordic countries total. Million tonnes of $\mathrm{CO}_{2}$-equivalents

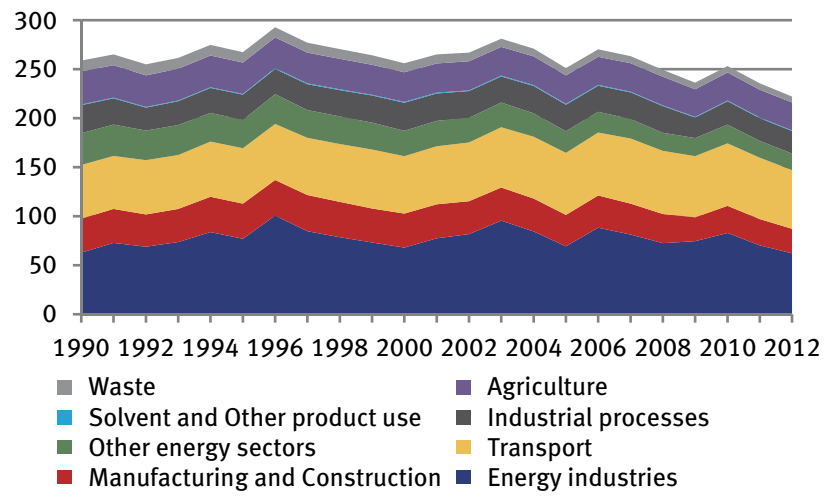

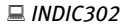

In both the Nordic countries and the EU, the energy industries and the transport sector account for the highest emissions of greenhouse gases. Except for the transport sector, all other sectors have had a decline in their emissions since 1990.

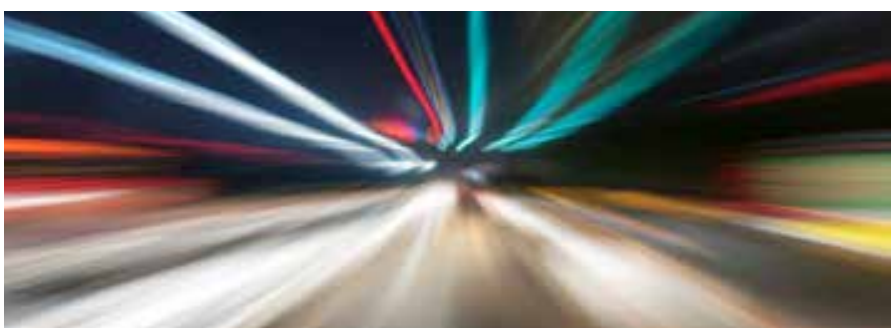


Greenhouse gas emissions by sectors. EU27 total. Million tonnes of $\mathrm{CO}_{2}$-equivalents

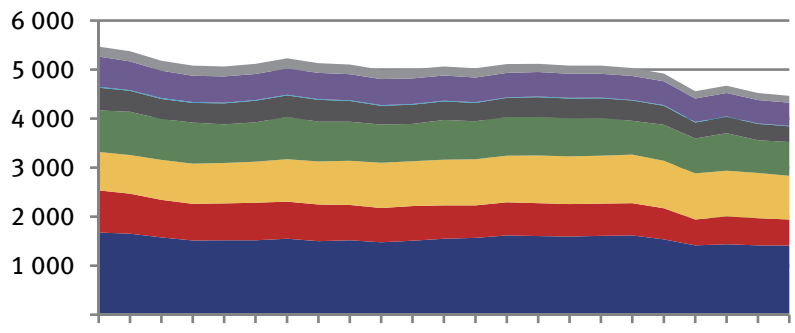

199019921994199619982000200220042006200820102012

- Waste

- Solvent and other product use

- Other energy sectors

- Manufacturing and construction
- Agriculture

- Industrial processes

- Transport

- Energy industries

品 INDIC302

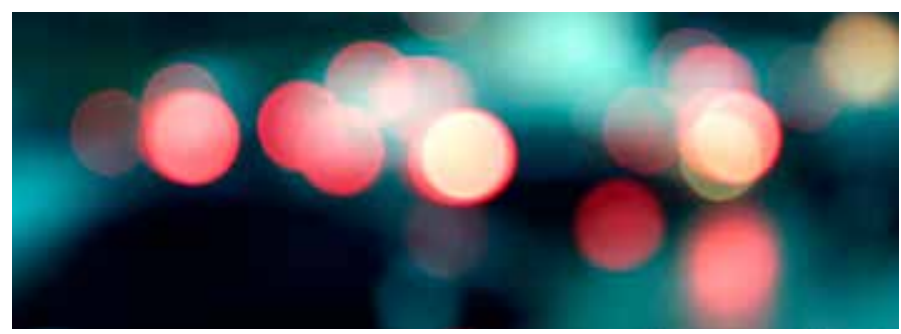




\subsection{Emissions and land use, land use change and forestry}

The indicator shows changes in emission and removals of greenhouse gases resulting from direct human-induced land use, land use change and forestry activities (LULUCF).

Whether emissions from this sector are positive or negative depends on the practices regarding forestation, deforestation, afforestation, cropland management, grazing land management and re-vegetation.

\section{Greenhouse gas emissions from LULUCF. 1000 tonnes of} $\mathrm{CO}_{2}$-equivalents per 100000 inhabitants

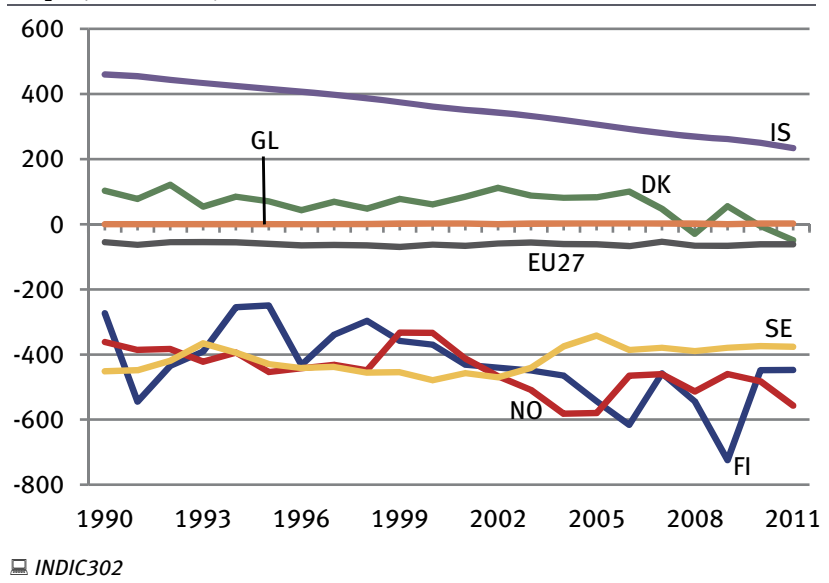

All the Nordic countries except Iceland now have a LULUCF sector that produces negative emissions of greenhouse gases. In the case of Denmark, this has only happened recently.

In terms of long-term development since 1990, emissions have been reduced considerably in all the Nordic countries except in Sweden. Norway now has the largest negative contribution. 


\section{Sustainable use of earth's resources}

\subsection{Decoupling of environmental pressures and economic growth}

This indicator shows the developments in greenhouse gas emissions, total energy consumption and the GDP since 1990, and gives an indication of a possible correlation between economic growth and environmental pressures and gross energy consumption.

GDP, energy consumption and greenhouse gas emissions. Nordic countries total

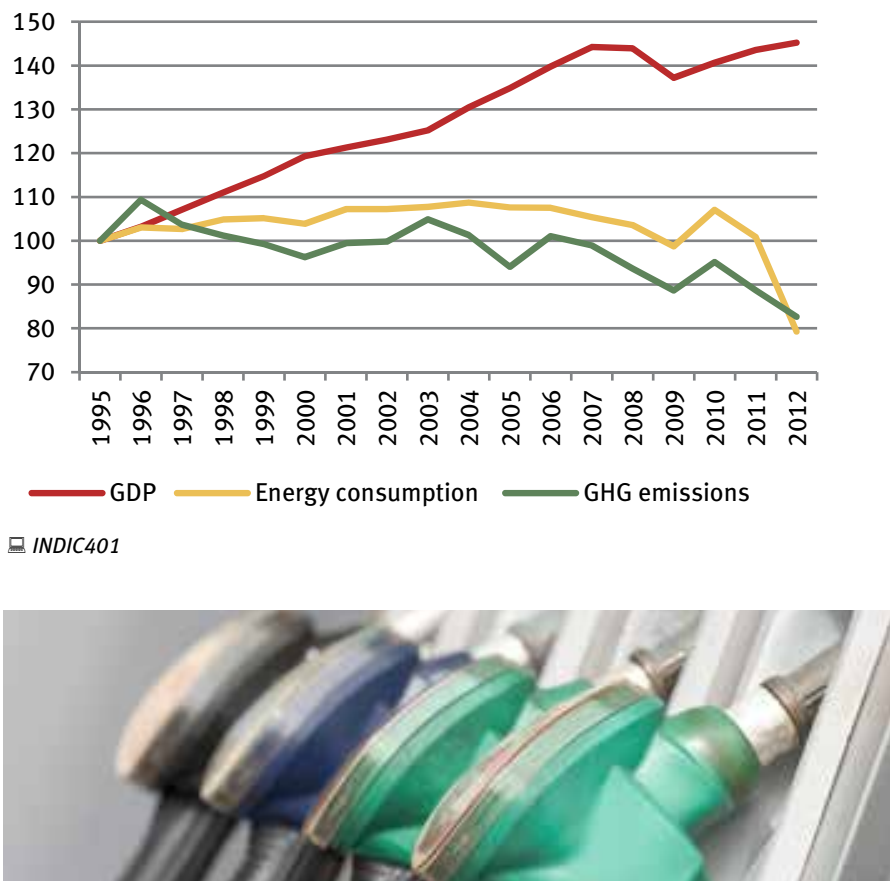




\section{GDP, energy consumption and greenhouse gas emissions. EU27 total}

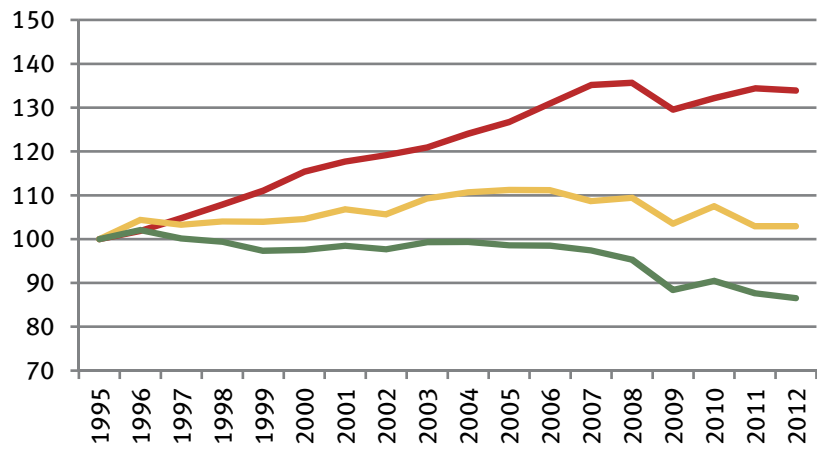

GDP

Energy consumption

GHG emissions

므. INDIC401

Between 1995 and 2012, energy consumption has decreased in the Nordic countries - a decrease of 20 per cent.

Considering the total greenhouse gas emissions in the same period, the overall tendency varies more between the Nordic countries. For the Nordic countries in total, there has been a decrease of 17 per cent in emissions from 1995 to 2012. In the same period, the GDP of the Nordic countries has increased by 45 per cent.

In the EU27, GDP has increased by nearly 34 per cent. At the same time, greenhouse gas emissions in the EU have fallen by 13.5 per cent, but total energy consumption has increased by 3 per cent. 


\subsection{Nordic Ecolabel and the EU Ecolabel}

The indicator shows the number of Nordic Ecolabel licences issued in the Nordic countries and the number of EU Ecolabel licences issued to Nordic producers.

\section{Number of ecolicences issued in the Nordic countries}

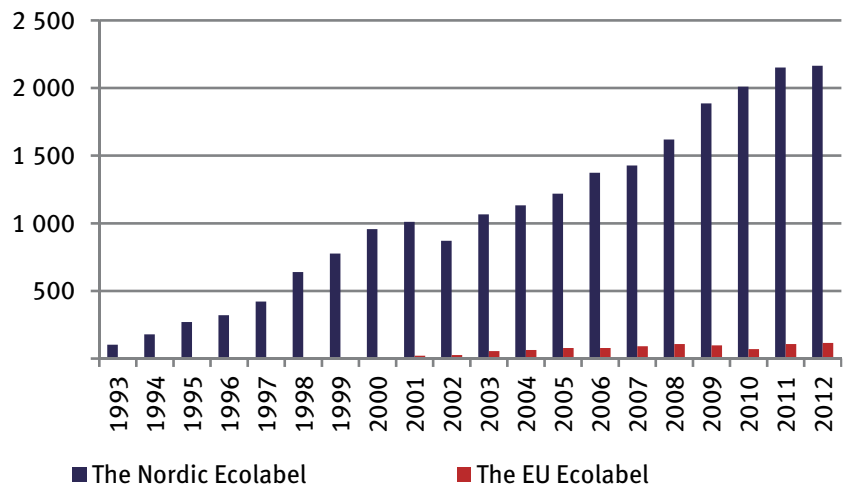

马INDIC402

Since the Nordic Ecolabel was set up in 1989, there has been a steady increase in the number of licences issued.

The number of EU Ecolabel licences has also increased but much more gradually, and there have been greater fluctuations and even a decline recently.

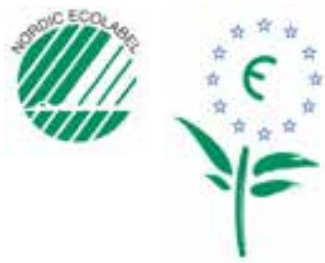




\subsection{Proportion of environmental taxes in total tax revenues}

The indicator shows the proportion of taxes with a primary environmental goal as a proportion of total tax revenues. Environmental taxes are divided into taxes on transport, energy taxes and taxes on pollution and resources.

\section{Environmental taxes. Per cent of total tax revenues}

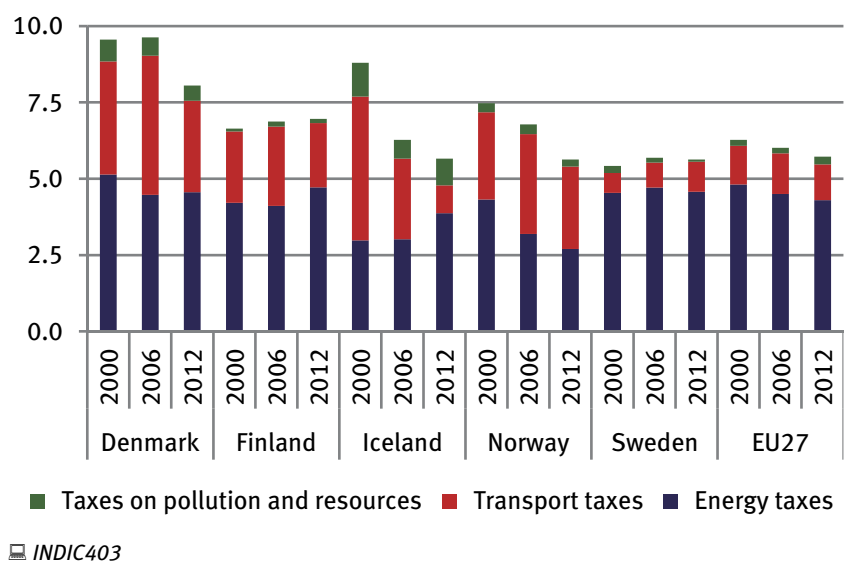

Environmental taxes have shown a downward trend since 2000 in Denmark, Iceland, Norway and the EU27. In Sweden and Finland, there has been a modest rise. Environmental taxes range from 5.6 per cent of the tax revenue in Norway and Sweden to 8.1 in Denmark.

In all the countries, taxes on energy comprise the largest proportion of environmental taxes followed by taxes on transport, while taxes on pollution and resources only account for a minimal proportion of total taxes. However, taxes on transport are still substantial in Denmark and Norway. 


\subsection{Development in municipal waste management by treatment method}

This indicator presents the quantities of municipal waste recovered through recycling and composting, as well as the amount disposed through landfilling and incineration.

\section{Treatment of municipal waste}

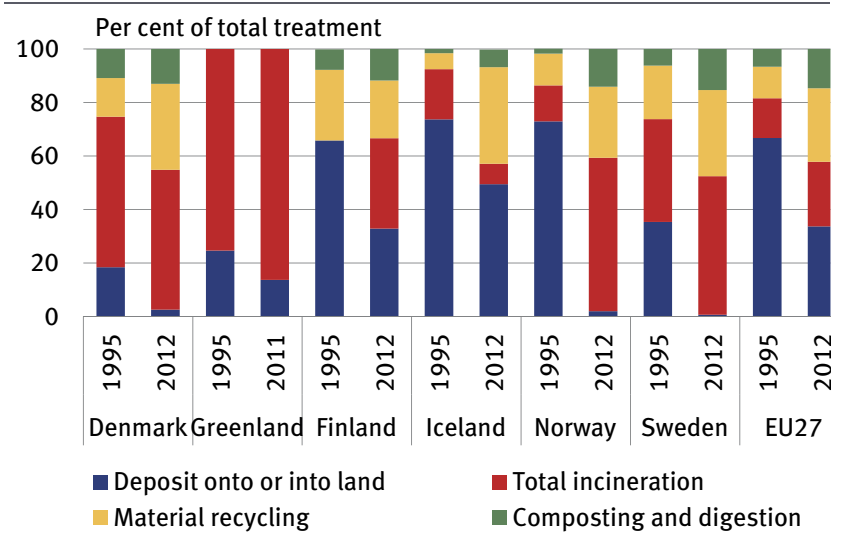

묘 INDIC404

Since 1995, the amount of waste being treated has gone up in all countries.

Finland and Iceland still deposit a large propotion of their waste onto or into the land. This is a treatment method that has almost completely disappeared in the three other Nordic countries. In all countries except Iceland, most waste is incinerated and often used for energy recovery.

Generally, material recycling has become a more important treatment type over the last 15 years. 


\section{Education, research and innovation}

\subsection{Educational attainment}

The indicator defines the percentage of the population aged 15-74 having reached UNESCO's International Standard Classification of Education (ISCED) level 3 and 4 (upper- and post-secondary education) and level 5 and 6 (tertiary education).

Educational attainment at upper- and post-secondary level. Per cent of total population aged 15-74

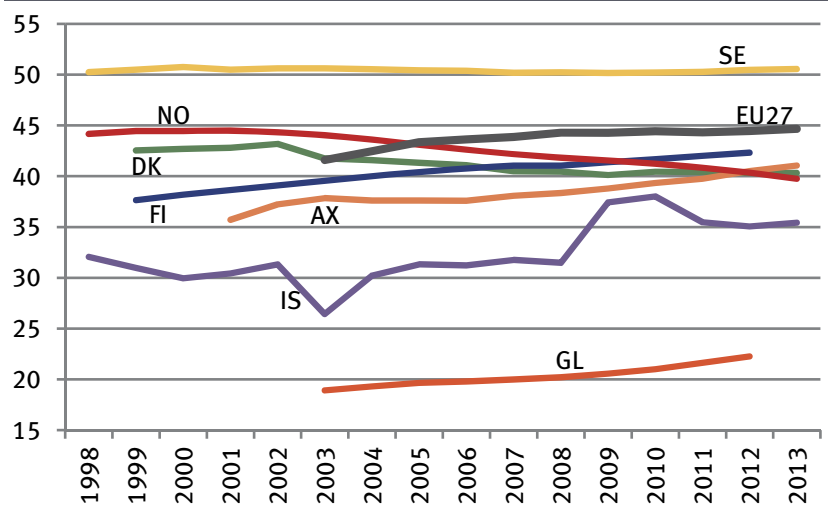

घ INDIC501

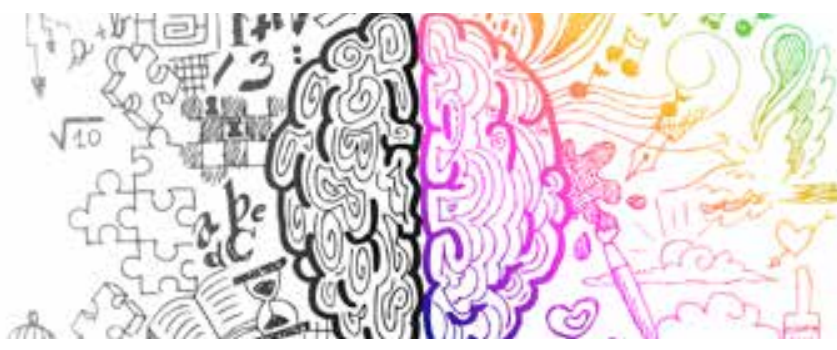


Between 35 and 50 per cent of the Nordic population aged 15-74 have a secondary education and 24 to 30 per cent a tertiary education.

\section{Educational attainment at tertiary level. Per cent of total population aged 15-74}

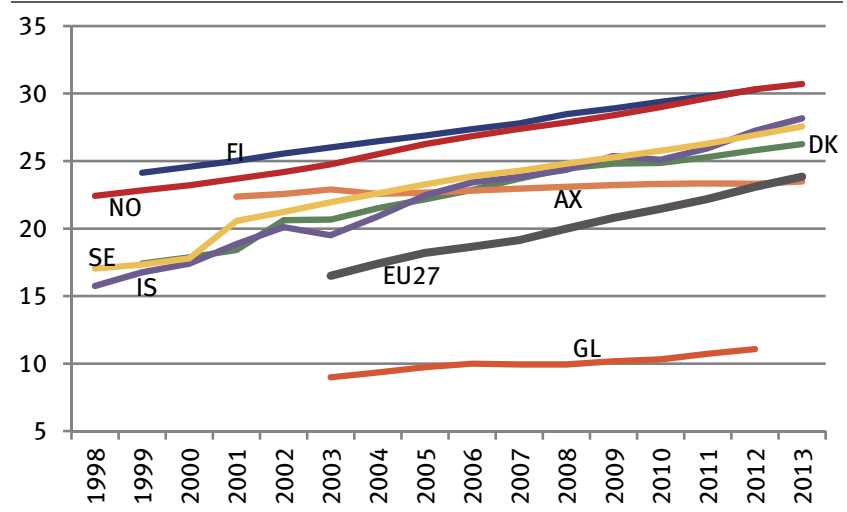

INDIC501

Finland and Norway have the highest proportion of people aged 15-74 with tertiary education, and Denmark has the lowest. When both secondary and tertiary levels are considered, Sweden has the highest propotion with 78 per cent, while, of the five Nordic countries, Iceland has the lowest with 64 per cent. Generally the educational attainment level is higher in the Nordic countries than in the EU countries as a whole.

The proportion of people having a tertiary education has been rising in all the Nordic countries - and in the EU - since the late 1990s. 


\subsection{Research and development expenditure. Percentage of GDP}

The indicator is defined as gross domestic expenditure on research and experimental development (GERD) as a percentage of GDP. The expenses are shown by performing sector.

Total R\&D expenditure by performing sector. Per cent of GDP

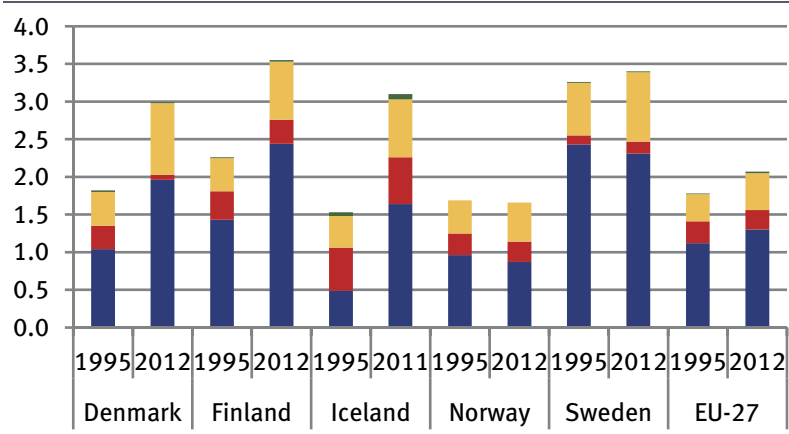

- Business and enterprise sector $\quad$ Government

- Higher education $\quad$ Private non-profit sector

묘 INDIC502

All the Nordic countries except Norway spend more on R\&D than the EU average of 2.0 per cent. Norway spends 1.7 per cent. However, if the Norwegian R\&D expenses were calculated in euro per person, spending would be higher due to Norway's extraordinarily high GDP.

While R\&D expenses in EU27 have constituted an unchanged proportion of GDP since the mid-1990s, the R\&D expenses of the Nordic countries again with the exception of Norway - have typically increased. 
www.norden.org/sdindicators www.norden.org/sdindicators www.norden.org/sdindicators

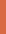

(1)

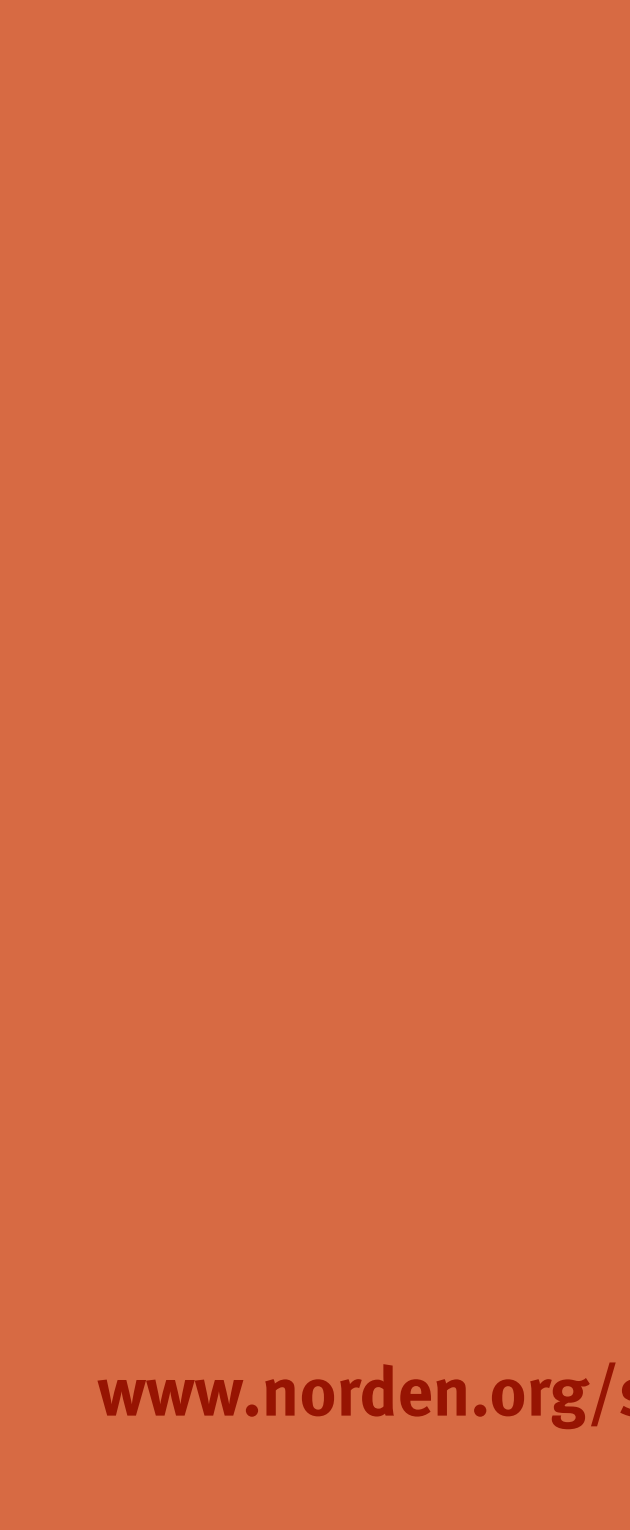




\section{norden}

Nordic Council of Ministers

Ved Stranden 18

DK-1061 Copenhagen K

www.norden.org

This brochure briefly describes the Nordic Sustainable Development Indicators, which show long-term trends in the following focus areas: the Nordic welfare model; viable ecosystems; changing climate; sustainable use of the earth's resources; and education, research and innovation.

A complete set of key indicators, including separate national graphics, can be found on the website www.norden.org/sdindicators. The website also offers free access to the Nordic Statistics database, which allows you to download data and create graphics for your own analysis.

www.norden.org/sdindicators

ANP 2014:755

ISBN 978-92-893-3810-3 (PRINT)

ISBN 978-92-893-3811-0 (PDF)
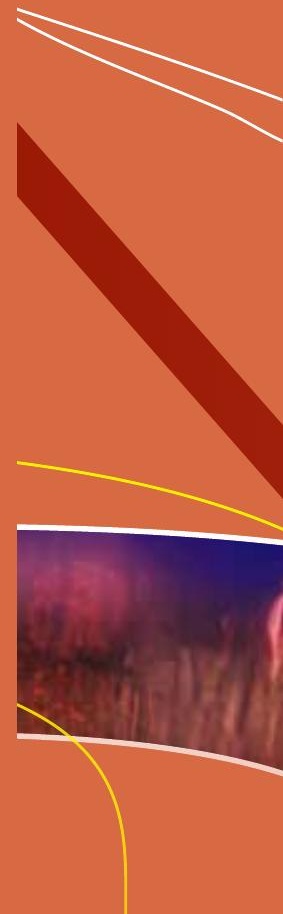